ISSN 2409-5613

\author{
A. V. Nechaev, A. A. Nechaev, A. A. Timina \\ Institute of Fundamental Education, Ural Federal University, \\ 28 Mira Str., Ekaterinburg, 620002, Russia. \\ Tel. (343) 375-45-68. \\ E-mail:a.v.nechaev@urfu.ru
}

\title{
Anodic behaviour of aluminium and its alloys in sodium chlorate solutions
}

The effect of chlorate ions on the anodic dissolution of aluminium and its alloys with magnesium under conditions of high current densities and intensive electrolyte mixing is investigated using the method of anodic polarisation curve removal on a rotating disk electrode.

It is shown that at relatively low anodic potential values the process is limited by the capacity of the electrochemical reaction, but with a further potential shift and a venting of the reaction products from the surface of the anode. The effective smoothing of the surface microrelief of aluminium alloys in solutions of chlorates is due to the periodic formation and destruction on the treated surface of a specific oxide film and inhibition due to the electrochemical heterogeneity of the structural components of the alloys.

Key words: anode potential; aluminium alloys; anodic polarization curves; sodium chlorate. Received: 25.11.2016; accepted: 29.01.2017; published: 14.04.2017.

\section{А. В. Нечаев, А. А. Нечаев, А. А. Тимина \\ Институт фундаментального образования \\ Уральский федеральный университет, Россия, 620002, Екатеринбург, ул. Мира, 28. Тел.(343) 375-45-68. \\ E-mail:a.v.nechaev@urfu.ru}

\section{Анодное поведение алюминия и его сплавов в растворах хлората натрия}

Методом снятия анодных поляризационных кривых на вращающемся дисковом электроде изучено влияние хлорат-ионов на анодное растворение алюминия и его сплавов с магнием при высоких плотностях тока в условиях интенсивного перемешивания электролита. Показано, что при сравнительно низких значениях анодного потенциала процесс лимитируется собственно электрохимической реакцией, а при дальнейшем сдвиге потенциала и отводом продуктов реакции от поверхности анода. Эффективное сглаживание микрорельефа поверхности алюминиевых сплавов в растворах хлоратов связано с периодическим образованием и разрушением на обрабатываемой поверхности специфической оксидной пленки и подавлением вследствие этого электрохимической гетерогенности структурных составляющих сплавов.

Ключевые слова: анодный потенциал; сплав алюминия; анодные поляризационные кривые; хлорат натрия.

Поступило: 25.11.2016; принято: 29.01.2017; опубликовано: 14.04.2017.

(C) Nechaev A. V., Nechaev A. A., Timina A.A, 2017 


\section{Introduction}

In solving problems associated with the electrochemical machining of aluminium alloys, an important role is played by an understanding of the laws of their anodic dissolution in an intensive electrolyte flow. Therefore, knowledge of these laws will al- low the optimal composition of the electrolyte to be chosen for the best mode for electrochemical machining of aluminium alloys, providing high accuracy and surface quality.

\section{Research Methodology}

In this paper, the study of the behaviour of aluminium alloy anodes used a rotating disc electrode to simulate the actual hydrodynamic conditions of the electrochemical process and provide an intense flow of electrolyte at the electrode surface [1].

In order to eliminate the resistive component in the measurement of the electrode potential, a rotating electrode design was created at the Chemical-Technological Institute of the Ural Federal University for the studied vertical movement relative to the very thin tip of the salt bridge of the reference electrode. The capillary of the reference electrode, having an external diameter of $0.1 \mathrm{~mm}$, was led into the centre of the disk by a distance not exceeding $0.07 \mathrm{~mm}$. In order to control the value of the resistive component in the values of the electrode potential, polarisation curves were taken at consecutive removing of the capillary from the surface of the electrode and then extrapolated to zero distance.

Moulded PTFE cylindrical rods with a diameter of $2 \mathrm{~mm}$, which had been degreased with ethanol directly prior to the experiment, were used for removing the polarization curves.

\section{Experimental part}

In sodium chlorate solutions, the anodic behaviour of aluminium and its alloys, like sodium chloride solutions, is characterised by areas of active dissolution and passivation.

Polarisation curves obtained for aluminium alloys in sodium chlorate solutions show a sharp increase in the anodic current density following activation of the anode potential. tance between the working electrode and the reference electrode capillary, anodic polarisation curves were recorded in potentiodynamic mode with linear scanning potential of $4 \mathrm{~B} / \mathrm{min}$ in a temperature controlled three-electrode glass cell with the divided anode and cathode spaces in solutions $\mathrm{NaClO}_{3}$ at $25^{\circ} \mathrm{C}$. A silver chloride electrode in a saturated solution of potassium chloride served as a reference electrode. For the auxiliary electrode, a platinum element was used.

Technological research was carried out on a pilot plant for electrochemical hole cutting in metals. In the experiments, the current density was varied between 50 and $250 \mathrm{~A} / \mathrm{cm}^{2}$ with an electrode gap of 0.05 to $0.1 \mathrm{~mm}$, electrolyte flow rate from 10 to $40 \mathrm{~m} / \mathrm{sec}$ and temperature between 20 and $60^{\circ} \mathrm{C}$.

Highly pure grade A995 aluminium and aluminium alloys AMg1, AMg3, AMg6, having varying magnesium content, formed the objects of study. 
However, when it reaches a certain density, the current reaches a limit in the speed of the anode process of dissolution of aluminium alloys - the current density falls with anode offset potential into the positive area and no further increases take place (Fig. 1).

A slight difference in the chemical composition of alloys is considered here in terms of the main alloying components (magnesium) having no significant impact on their anodic behaviour; this is determined by the base alloy component, i. e. aluminium.

Along with the concentration of the electrolyte, the influence of the electrolyte temperature and speed of rotation of the disc electrode on the intensity of anodic dissolution of aluminium alloy (Fig. 2) were also studied.

In the study of the anodic behaviour of the investigated aluminium alloys depending on the temperature of the solution, the rotating speed of the disk electrode showed that the maximum current density on the anodic polarisation curves increases with a decreasing concentration of sodium chlorate solution from $5 \mathrm{M}$ to $3 \mathrm{M}$ (Fig. 1), as well as with an increase in electrolyte temperature (Fig. 2) and with an increase in the rotational speed of the disk electrode (Fig. 2).

It can be assumed that in sodium chlorate solutions, as in chloride solutions, the passivation of aluminium and aluminium alloys of AMg6 type occurs due to the formation of a salt film on the surface of the electrode.

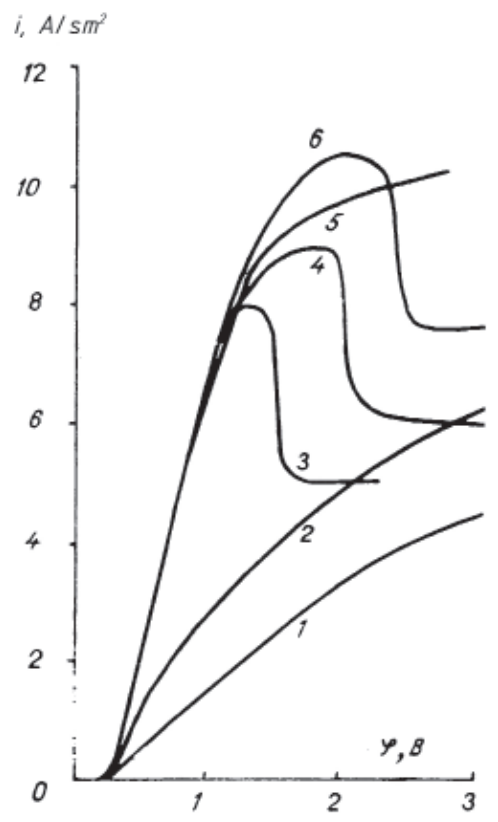

Fig. 1. Potentiodynamic polarisation curves for AMg6 alloy captured on a rotating disk electrode in sodium chlorate solutions of various concentrations ( $\mathrm{mol} / 1): 1-0,5 ; 2-1,0$; $3-5,0 ; 4-4,0 ; 5-2,0 ; 6-3,0$.

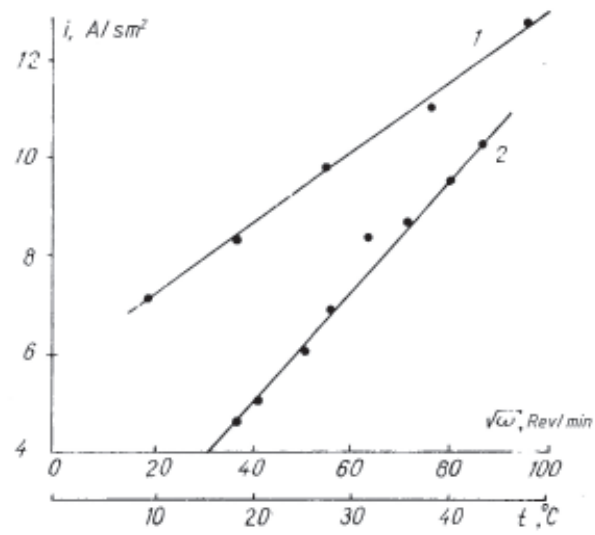

Fig. 2. Effect of temperature (1) and speed of rotation of disc electrode (2) on the maximum current density dissolution of aluminium alloy AMg6 in 4M sodium chlorate

\section{Results and Discussion}

Processing of the experimental data using the temperature-kinetic method showed that the value of the effective activation en- ergy of the dissolution process of the alloy in $\mathrm{AMg} 6 \mathrm{NaClO}_{3}$ solutions decreases from 7.05 to $7>2.4 \mathrm{kcal} / \mathrm{mol}$ with increasing 
polarisation from 0.8 to $1.7 \mathrm{~B}$. Therefore, at relatively low anode potential values, the alloy dissolution process is limited by the electrochemical reaction, and, when a certain potential is reached - withdrawal of the reaction products from the surface of the anode [2].

The presence of diffusion limitations at the time of active dissolution of the alloy also shows the maximum dependence of the current density on the polarisation curve on the speed of the rotation disc electrode (Fig. 2).

This may also indicate the fact that the maximum current value before the beginning of passivation increases almost linearly with an increase in temperature of the electrolyte owing to increased solubility of the salt film.

With a further shift of the potential of the aluminium electrode to a positive region in sodium chlorate solutions, no new sharp

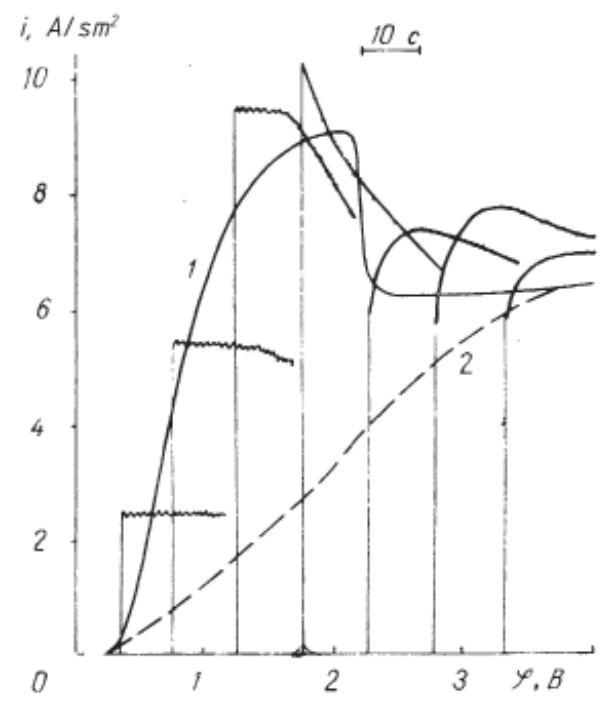

Fig. 3. Anodic polarisation curve of current density - time at different potentials, taken on a rotating disk electrode for AMg6 alloy in $4 \mathrm{M}$ sodium chlorate solution 1 - forward stroke of polarisation curve, 2 - return stroke of polarisation curve increase in current density was observed after reaching the maximum current density, as was the case in the solutions of sodium chloride. This behaviour of the aluminium anode in solutions of $\mathrm{NaClO}_{3}$ can be explained by the fact that film passivation of a more complex nature may occur after the formation of a salt film on the electrode.

To some extent this shows the dependence of current on time (Fig. 3.).

Although they were in evidence in the sodium chloride solution, no clearly expressed peaks were present with potentiostatic closure in the region of significant polarisations. More complex secondary passivation layers, probably on the part of aluminium oxide compounds, are formed in sodium chlorate solutions. The formation of a number of different oxide films on the metals in the sodium chlorate solutions was noted in [3]. Since in the passive region, the current of the anodic dissolution is only somewhat less than the maximum it is possible to assert that the resultant oxide film on the anode does not prevent the anodic dissolution of aluminium alloys in the solutions of sodium chlorate. When directly viewed through a microscope, a film can be clearly seen forming on the surface of the aluminium electrode during dissolution; this almost immediately disintegrates into fragments, exposing the surface of the electrode.

Moreover, transportation of metal ions from the anode surface may occur by migration through the film. According to [4] structural defects are present in an ionic oxide lattice: either cationic and anionic components are unoccupied, or, alternatively, ions introduced in the interstices of the lattice, whereby the diffusion of ions and electrons can occur in the oxide layer. The intensity of the dissolution of the metal 
will depend on the speed of movement of ions through the atomic lattice of the oxide.

In electrochemical treatment of aluminium alloys in sodium chlorate solutions, a high purity of the treated surface is achieved. Effective smoothing of the microrelief and high purity of the treated surface following electrochemical treatment of aluminium alloys in sodium chlorate solutions can be linked to the formation of specific oxide films on the surface of the electrode and suppression thereby of the electrochemical heterogeneity of structural components of aluminium alloys by an additional potential barrier at the metal boundary, consisting of a film that also reduces the extent of etching. In this case, there is a redistribution of the potentials of various structural components of the alloy, which leads to their levelling and a consequent smoothing of the microrelief.
This is to some extent confirmed by metallographic studies of the aluminium alloy surface following electrochemical treatment in sodium chlorate solutions, which showed the absence of any intergranular violations of the grain boundary.

In nitrate solutions, the activation potential of aluminium and its alloys with magnesium is almost two volts higher than in sodium chlorate solutions. Therefore, from the standpoint of energy consumption, treatment of aluminium alloys using a sodium chlorate based electrolyte is preferable.

Thus, along with high quality electrochemical machining in the complete absence macroscopic defects on the treated surface, a high level of productivity in processing aluminium alloys is achievable using chlorate solutions.

\section{In Russian}

\section{Введение}

В решении проблем электрохимической обработки алюминиевых сплавов немаловажную роль играют закономерности их анодного растворения в интенсивном потоке электролита. Поэтому знание этих закономерностей позволит выбрать состав электролита и оптимальный режим для обработки алюминиевых сплавов, обеспечивающий высокую точность и качество обрабатываемой поверхности.

\section{Методика исследований}

В данной работе при изучении анодного поведения алюминиевых сплавов был применен вращающийся дисковый электрод, реально имитирующий гидродинамические условия электрохимической обработки и обеспечивающий интенсивный поток электролита у поверхности электрода [1].

Для элиминирования омической составляющей при измерении электродного потенциала в Химико-техно- логическом институте Уральского федерального университета специально была создана конструкция установки вращающегося электрода, обеспечивающая вертикальное перемещение изучаемого электрода относительно очень тонкого носика электролитического ключа электрода сравнения. Капилляр электрода сравнения с внешним диаметром не более 0,1 мм подводился к центру диска на расстояние, не превышаю- 
щее 0,07 мм. Для контроля величины омической составляющей в значения величины потенциала электрода снимались поляризационные кривые при последовательном удалении капилляра от поверхности исследуемого электрода с последующей экстраполяцией их на нулевое расстояние.

Для снятия поляризационных кривых использовались запрессованные во фторопласт цилиндрические стержни диаметром 2 мм, которые непосредственно перед экспериментом обезжиривались этанолом.

С целью уменьшения растворения электрода и в связи с этим увеличения расстояния между рабочим электродом и капилляром электрода сравнения анодные поляризационные кривые снимались в потенциодинамическом режиме при линейной развертке потенциала $4 \mathrm{~B} /$ мин в термостатированной трех электродной стеклянной ячейке с разделенным анодным и катодным пространствами в растворах $\mathrm{NaClO}_{3}$ при температуре $25^{\circ} \mathrm{C}$. Электродом сравнения служил хлорсеребряный электрод в насыщенном растворе хлорида калия. Вспомогательным электродом служила платина.

Технологические исследования проводились на опытной установке для электрохимической прошивки отверстий в металлах. При проведении экспериментов плотность тока менялась от 50 до $250 \mathrm{~A} / \mathrm{cm}^{2}$, межэлектродный зазор - от 0,05 до 0,1 мм, скорость течения электролита - от 10 до $40 \mathrm{M} / \mathrm{c}$, температура - от 20 до $60^{\circ} \mathrm{C}$.

В качестве объектов исследования использовалась алюминий марки А995 и алюминиевые сплавы АМц, АМг1, АМг3, АМг6, содержащие в своем составе различное содержание магния.

\section{Экспериментальная часть}

В растворах хлората натрия анодное поведение алюминия и его сплавов, подобно растворам хлорида натрия, характеризуется областью активного растворения и пассивацией.

Поляризационные кривые, полученные для алюминиевых сплавов в растворах хлората натрия, свидетельствуют, что после потенциала анодной активации наблюдается резкий рост анодной плотности тока.

Однако при достижении определенной плотности тока наступает ограничение скорости анодного процесса растворения алюминиевых сплавов плотность тока падает при смещении потенциала анода в положительную область и в дальнейшем не увеличивается (рис. 1).

Незначительное отличие химического состава рассматриваемых нами сплавов по основному легирующему компоненту (магнию) не повлияло существенно на их анодное поведение, которое определяется основным компонентом сплава - алюминием.

Наряду с концентрацией электролита исследовано влияние температуры электролита и скорости вращения дискового электрода на интенсивность анодного растворения алюминиевых сплавов (рис. 2).

Изучение анодного поведения исследуемых алюминиевых сплавов в зависимости от температуры раствора скорости вращения дискового электрода показало, что максимальная плотность тока на анодных поляризационных кривых с понижением концентрации 
раствора хлората натрия от $5 \mathrm{M}$ до $3 \mathrm{M}$ (рис. 1), а также с ростом температуры электролита (рис. 2) и увеличением ско-

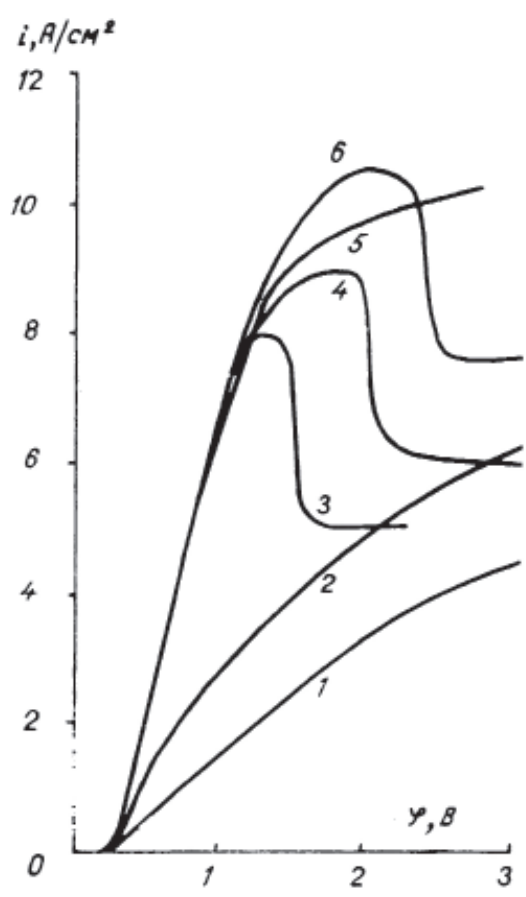

Рис. 1. Потенциодинамические поляризационные кривые для сплава АМг6, снятые на вращающемся дисковом электроде в растворах хлората натрия различной концентрации (моль/л): $1-0,5$; $2-1,0 ; 3-5,0 ; 4-4,0 ; 5-2,0 ; 6-3,0$ рости вращения дискового электрода (рис. 2) возрастает.

Можно предположить, что в растворах хлората натрия, как и в растворах хлоридов, пассивация алюминия и алюминиевых сплавов типа АМг6 наступает вследствие образования на поверхности электрода солевой пленки.

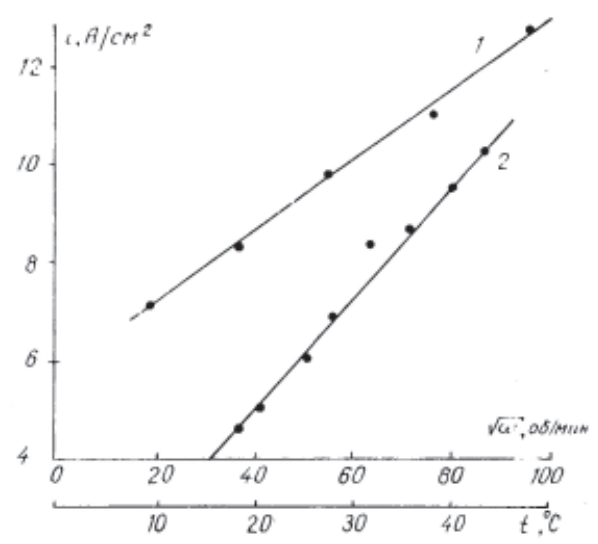

Рис. 2. Влияние температуры (1) и скорости вращения дискового электрода

(2) на максимум плотности тока растворения алюминиевого сплава АМг6 в $4 \mathrm{M}$ раствора хлората натрия

\section{Результаты и их обсуждение}

Обработка полученных экспериментальных данных температурно-кинетическим методом показала, что значение эффективной энергии активации процесса растворения сплава АМг6 в растворах $\mathrm{NaClO}_{3}$ уменьшается от 7,05 до $7>2,4$ ккал/моль с ростом поляризации от 0,8 до 1,7 В. Следовательно, при сравнительно низких значениях анодных потенциалов процесс растворения сплава лимитируется собственно электрохимической реакцией, а при достижении определенного потенциала - отводом продуктов реакции от поверхности анода [2].

О наличии диффузионных ограничений в момент активного растворения сплава свидетельствует и зависимость максимальной плотности тока на поляризационной кривой от скорости вращения дискового электрода (рис. 2).

Об этом может также свидетельствовать и то, что с повышением температуры электролита, вследствие увеличения 
растворимости солевой пленки, величина максимального тока до начала пассивации возрастает практически линейно.

При дальнейшем сдвиге потенциала алюминиевого электрода в положительную область в растворах хлората натрия не наблюдалось нового резкого повышения плотности тока после достижения максимума плотности тока, как это имело место в растворах хлорида натрия. Такое поведение алюминиевого анода в растворах $\mathrm{NaClO}_{3}$ может быть связано с тем, что вслед за образованием солевой пленки на электроде может возникать пассивная пленка более сложной природы.

Об этом в какой-то мере свидетельствует зависимость ток-время (рис. 3).

При потенциостатическом включении в области больших поляризаций

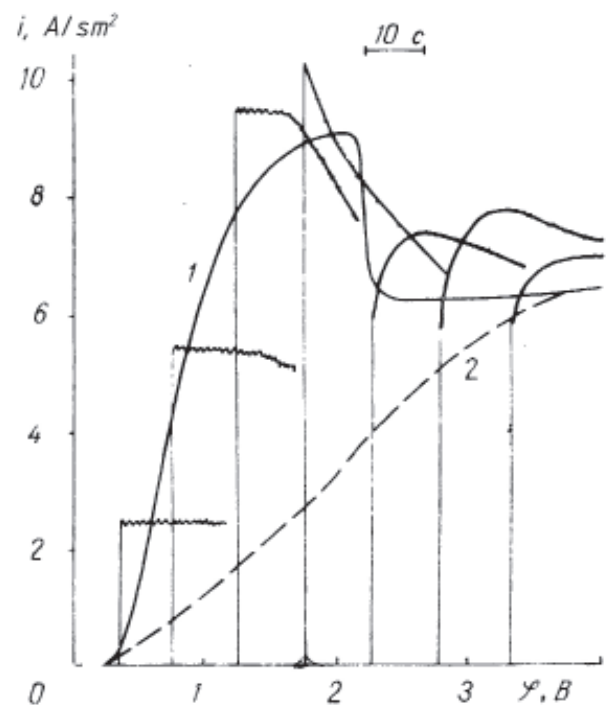

Рис. 3. Анодная поляризационная кривая и зависимости плотность тока время при различных потенциалах, снятые на вращающемся дисковом электроде для сплава АМг6 в 4М растворе хлората натрия: 1 - прямой ход поляризационной кривой; 2 - обратный ход поляризационной кривой отсутствовали ярко выраженные пики, в то время как в растворе хлорида натрия они имели место. В растворах хлората натрия вторичные более сложные пассивирующие слои, по всей вероятности, образованы оксидными соединениями алюминия. Образование различных по природе оксидных пленок на металлах в растворах хлората натрия отмечалось в работе [3]. Поскольку в пассивной области ток анодного растворения лишь немного меньше максимального, можно утверждать, что образующаяся на аноде оксидная пленка не препятствует анодному растворению алюминиевых сплавов в растворах хлората натрия. При наблюдении в микроскоп за поверхностью алюминиевого электрода непосредственно в процессе его растворения отчетливо было видно образование на поверхности электрода пленки, которая почти сразу же разрушалась на отдельные фрагменты, оголяя поверхность электрода.

Кроме того, транспорт металлических ионов с поверхности анода может происходить и посредством их миграции через эту пленку. В ионной решетке оксида имеются структурные дефекты: незанятые катионные и анионные узлы, или, наоборот, ионы, внедренные дополнительно в междуузлия решетки, в результате чего может происходить диффузия ионов и электронов в слое оксида [4]. Интенсивность растворения металла будет зависеть и от скорости движения ионов сквозь атомную решетку оксида.

При электрохимической обработке алюминиевых сплавов в растворах хлората натрия достигается высокая чистота обрабатываемой поверхности. Эффективное сглаживание микрорельефа и высокая чистота обрабатываемой 
поверхности после электрохимической обработки алюминиевых сплавов в растворах хлората натрия могут быть связаны с образованием на поверхности электрода специфической оксидной пленки и подавлением вследствие этого электрохимической гетерогенности структурных составляющих алюминиевых сплавов за счет дополнительного потенциального барьера на границе металл - пленка, что и приводит к уменьшению масштабов травления. В этом случае происходит перераспределение потенциалов различных структурных составляющих сплава, приводящее к их выравниванию и сглаживанию микрорельефа.

Это в определенной степени подтверждается металлографическими исследованиями поверхности алюминиевых сплавов после их электрохимической обработки в растворах хлората натрия, которые показали отсутствие какихлибо межкристаллитных нарушений по границам зерен.

В растворах нитратов потенциал активации алюминия и его сплавов с магнием почти на два вольта больше, чем в растворе хлората натрия. Поэтому с точки зрения энергетических затрат использование для обработки алюминиевых сплавов электролита на основе хлората натрия предпочтительно.

Таким образом, в растворах хлоратов наряду с хорошим качеством электрохимической обработки алюминиевых сплавов достигается высокая производительность процесса при полном отсутствии макродефектов на обрабатываемой поверхности.

\section{References}

1. Davydov A. D., Knotz L. L., Kashcheev V. D., Kuchnev V.V. Study of electrode processes potentiokinetic method with respect to electrochemical processing of metals. Electronic processing of materials. 1969;2:82-87.

2. Amirkhanova N. A., Khaydarov R. R. Determination of the limiting stages of the highspeed dissolution of aluminum alloy with CZ and UMP structure. Vestnik Ufimskogo gosudarstvennogo aviazionnogo tekhnicheskogo universiteta. 2007:9(1);117-121.

3. Romashkan A. D., Davydov D. A., Kashcheev V.D., Kabanov B. N. Dissolution of iron in solutions of sodium chlorate at high anodic potentials. Electrochemistry. 1974;10(1):109112.

4. Bernard D. J. Oxidation of metals. Vol. 1. Metallurgiya, 1968.

\section{Cite this article as (как цитировать эту статью):}

Nechaev A. V., Nechaev A. A., Thymina A. A. Anodic behavior of aluminium and its alloys in solutions of sodium chlorate. Chimica Techno Acta. 2017;4(1):45-53. 